TEACHING : Jurnal Inovasi Keguruan dan IImu Pendidikan

Vol. 1. No. 3 September 2021 e-ISSN : 2775-7188 | p-ISSN : 2775-717X

\title{
BEST PRACTISE MENINGKATKAN LITERASI TEKNOLOGI DAN SAIN PESERTA DIDIK MELALUI PEMBELAJARAN BERBASIS PROYEK DENGAN PENDEKATAN STEM
}

\author{
ARI SATRIANA \\ MAN 1 Yogyakarata \\ Email : Arisatrianaman1@gmail.com
}

\begin{abstract}
ABSTRAK
Fisika adalah cabang ilmu pengetahuan terdiri dari beberapa konsep dasar berbagai fenomena yang terjadi dalam kehidupan sehari-hari. Inegrasi ilmu fisika diharapkan menjadi fondasi dalam membangun bangsa menyongsong era Revolusi industri 4.0 yang mensyaratkan sumber daya manusia berkualitas dengan ketrampilan abad 21. Dalam pembelajaran fisika penguasaan pendekatan science, technology, engineering, and mathematic (STEM) menjadi sangat penting y ang memungkinkan peserta didik mempelajari konsep akademik secara tepat dan berbasis pada masalah atau Problem-Based Learning (PjBL). Tujuan dibuatnya Best Practice penerapan model pembelajaran berbasis masalah dengan pendekatan STEM adalah : 1) mendeskripsikan respon peserta didik, 2) mendeskripsikan peningkatan literasi teknologi dan literasi sain, dan 3) mendeskripsikan ketuntasan hasil belajar Fisika peserta didik. Penelitian ini menggunakan pendekatan kuantitatif dengan metode analisis deskriptif kuantitatif. Penelitian ini dilaksanakan pada bulan januari 2020 pada pembelajaran Fisika di kelas X Peminatan MIPA MAN 1 Yogyakarta. Pengumpulan data dengan metode teknik tes, observasi, angket, dokumentasi dan penilaian proyek/produk. Analisis data dengan menggunakan analisis deskriptif. Hasil penelitian menunjukkan bahwa : 1) Rerata respon peserta didik sebesar 85\% atau dengan kategori sangat baik, 2) Peningkatan rerata nilai literasi teknologi dari 41,93 menjadi 80,99 dan rerata literasi sain dari 53,52 menjadi 84,96, 3) Nilai rerata postes literasi teknologi sebesar 80,99 dan nilai rerata postes literasi sain sebesar 84,96 di mana nilai rerata hasil belajar ini melampaui nilai KKM (75). Dengan demikian, pembelajaran proyek berbasis masalah dengan pendekatan STEM dapat menunjukkan kepada peserta didik bagaimana konsep, prinsip, sains, teknologi, teknik, dan matematika digunakan secara terintegrasi untuk mengembangkan produk, proses, dan sistem yang bermanfaat bagi kehidupan manusia. Oleh karena itu, guru sebaiknya dapat merancang pembelajaran dengan langkah-langkah yang tepat sehingga pelaksanaannya dapat berjalan sesuai dengan rencana yang telah ditentukan.
\end{abstract}

Kata kunci : Literasi Teknologi, Literasi sain, Pembelajaran berbasis Proyek dengan Pendekatan STEM.

\section{PENDAHULUAN}

Tenaga pendidik di era teknologi adalah orang yang mampu menghantarkan peserta didiknya tidak hanya melek/literasi sain tetapi juga literasi teknologi. Para pemangku kepentingan di lingkungan pendidikan diharapkan mampu merespon positif perubahan era revolusi industri 4.0 ini (Nopilda, 2018). Menghadapi tantangan revolusi industri 4.0 ini perlu dikembangkan literasi dalam segala aspek kehidupan ( Irianto, 2017). Literasi dikenal sebagai kemampuan membaca, namun seiring berjalannya waktu literasi mengalami peluasan makna (Akbar; 2017). Dalam perkembangannya, muncul istilah literasi baru yang mengkaitkan dengan kemampuan-kemampuan lain seperti ekonomi, politik, teknologi (Naraian, 2014). Gerakan literasi baru yang dicanangkan pemerintah yaitu literasi teknologi (Ristekdikti, 2017)

Beberapa aspek pada literasi teknologi mencakup tentang mengenal teknologi berdasarkan fungsinya, memahami sistem yang bekerja pada teknologi, strategi pemecahan masalah, memahami penerapan teknologi dalam kehidupan sehari-hari ( Ahmad, 2018). Literasi teknologi penting untuk ditingkatkan, karena pada era revolusi industri ini erat kaitannya dengan teknologi (Cydis, 2015). Isi pengajaran dari kurikulum seharusnya berkaitan dengan teknologi, khususnya teknologi yang ada dalam kehidupan sehari-hari maka literasi teknologi 
dapat ditingkatkan dengan menyelesaikan permasalahan teknologi yang ada dan melakukan eksperimen/ proyek pada teknologi yang sering dijumpai (Dincer, 2019). Penggunaan teknologi dalam proses belajar mengajar merupakan suatu hal yang penting untuk mendukung pembelajaran karena membuat pembelajaran menjadi lebih bermakna serta untuk memenuhi kompetensi peserta didik di abad 21 (Astuti, 2020).

Namum pada kenyataannya kemampuan literasi teknologi peserta didik masih tergolong rendah, dilihat dari aspek memahami solusi dari suatu permasalahan pada teknologi (Anjarsari, 2020). Penelitian lain menunjukkan bahwa peserta didik Sekolah Menengah Atas (SMA) memiliki kemampuan literasi teknologi yang masih buruk karena pembelajaran fisika yang diselenggarakan tidak mengakomodasi peserta didik untuk menumbuhkembangkan literasi teknologi (Avsec, 2017).

Literasi sains juga merupakan salah satu dari kompetensi yang diperlukan pada abad 21 (Acedo \& Hughes, 2014). Kemampuan literasi sains peserta didik tergolong rendah pada aspek kompetensi, yang terdiri dari menjelaskan fenomena secara ilmiah, mengidentifikasi topik ilmiah dan penggunaan bukti ilmiah, hal ini dikarenakan siswa kurang familiar dan paham dengan topik ilmiah (Purwani, 2018).

Pendidikan sains telah diterapkan di Indonesia selama bertahun-tahun akan tetapi literasi sains peserta didik Indonesia masih rendah. Hal tersebut disebabkan karena guru sering kali mengajarkan rumus dibandingkan dengan konsep, peserta didik kurang memahami konsep dasar yang diajarkan guru, peserta didik masih bimbang dengan pernyataan guru yang tidak disertai dengan penjelasan secara ilmiah, peserta didik lebih banyak menghafal materi (Rusilowati, 2016). Aspek pengetahuan dan kompetensi literasi sains perlu ditingkatkan terutama dalam hal mengevaluasi bukti ilmiah, peserta didik harus diberikan kesempatan untuk dapat membandingkan data eksperimen mereka dengan teori.

Salah satu ilmu yang mendasari berkembangnya teknologi dan sains ialah fisika. Fisika banyak dimanfaatkan dalam berbagai bidang kehidupan seperti teknologi, pendidikan, teknik dan bidang kehidupan lainnya. Akan tetapi pada masa sekarang masih banyak persoalan yang terjadi pada proses belajar dan pembelajarannya. Pembelajaran di kelas masih banyak yang menerapkan metode ceramah (Utami, 2017). Guru masih menerapkan pembelajaran yang berpusat pada pendidik daripada peserta didik (Maharani, 2019), menyampaikan materi secara abstrak dan teoritik serta peserta didik pasif hanya mendengarkan ceramah dari guru (Pearson, 2017). Penerapan strategi pembelajaran fisika masih mengandung unsur matematis dan tidak kontekstual, menjadikan peserta didik menganggap fisika merupakan pelajaran yang sulit (Akmam, 2018). Peserta didik jarang sekali diajak belajar terkait dengan pengaplikasian konsep fisika yang dipelajari dalam membuat suatu produk teknologi (Millaturrahmah, et.al, 2017). Umumnya peserta didik sudah menyadari bahwa fisika itu penting dan berguna dalam kehidupan sehari-hari sehingga perlu dipelajari, tetapi pada kenyataanya mereka belum paham akan kegunaan fisika dalam kehidupan sehari-hari (Irianto, et.al, 2017).

Berdasarkan pemaparan diatas, diperlukan model dan pendekatan agar tujuan pembelajaran peserta didik tercapai. Model pembelajaran yang berpusat pada peserta didik adalah pembelajaran berbasis proyek. Pembelajaran berbasis proyek melibatkan peserta didik dalam pembelajaran mampu meningkatkan motivasi dan semangat belajar (Hugerat, 2016). Pembelajaran berbasis proyek dapat mengasah kemampuan peserta didik untuk menganalisis dan mengevaluasi secara kritis aspek-aspek penting dari literasi (Archer, 2017), membantu mengenalkan dan meningkatkan literasi teknologi peserta didik (Cydis, et.al, 2015), efektif dalam meningkatkan pemecahan masalah serta peserta didik mampu belajar mandiri dan kolaboratif .

Model pembelajaran berbasis proyek dapat diintegrasikan dengan salah satu pendekatan yaitu STEM (Science Technology Engineering Mathematics). Pendekatan STEM dalam pembelajaran menghubungkan materi dengan kehidupan sehari-hari, melibatkan peserta didik dalam praktik, membimbing peserta didik dalam praktik, memanfaatkan teknologi (komputer, internet), menggunakan strategi pembelajaran aktif, berkomunikasi secara aktif dengan peserta 
didik selama pembelajaran, memberikan tugas dalam kelompok, menggunakan pemecahan masalah (Alifa, 2018). Pendekatan STEM diperlukan dalam menghadapi abad ke 21 (Rahmayani, 2018). Pembelajaran yang mengintegrasikan STEM membuat mata pelajaran lebih relevan bagi peserta didik sehingga peserta didik mampu memahami konsep dengan menghubungkan penerapan dari ilmu pengetahuan pada kehidupan nyata, meningkatkan motivasi, kreativitas, prestasi dan memberikan pengalaman dalam pemecahan masalah menggunakan teknologi (Lestari, 2018).

Pembelajaran proyek dengan pendekatan STEM mengharuskan peserta didik memecahkan permasalahan kontekstual berdasarkan konsep STEM (Capraro \& Slough, 2015). Kurikulum pembelajaran berbasis proyek dengan pendekatan STEM dirancang berdasarkan kehidupan sehari-hari (Hanif, 2019). Penerapan pembelajaran berbasis proyek dengan pendekatan STEM melalui kegiatan kolaboratif melibatkan peserta didik untuk berpikir pada suatu permasalahan yang kompleks, mengasah daya pikir dan nalar mereka serta mempersiapkan peserta didik untuk menghadapi tantangan abad 21 (Jamali, 2017).

Berdasarkan pertimbangan tersebut, inovasi pembelajaran sangat diperlukan untuk mendukung tuntutan kompetensi abad 21. Salah satunya adalah pembelajaran berbasis proyek dengan pendekatan STEM yang bertujuan untuk meningkatkan literasi teknologi dan sains. Manfaat setelah berbagi pengalaman melalui best practice ini : 1) Bagi peserta didik, dapat meningkatkan literasi teknologi dan sains serta hasil belajar setelah diimplementasikannya proses pembelajaran, 2) Bagi guru, best practice ini diharapkan dapat memberikan kontribusi keilmuan di masa mendatang serta sebagai bahan kajian untuk meningkatkan profesionalisme guru.

\section{METODE PELAKSANAAN}

Penelitian ini merupakan penelitian deskriptif yang menggambarkan bagaimana suatu pembelajaran fisika berbasis proyek dengan pendekatan STEM yang diterapkan dan bagaimana hasil yang diinginkan dapat dicapai. Sasarannya adalah peserta didik MAN 1 Yogyakarta kelas X MIPA.

Tahapan, fase atau sintak pembelajaran berbasis proyek dengan pendekatan STEM untuk meningkatkan literasi teknologi dan sains ditunjukkan pada tabel 1.

\section{Tabel 1. Sintaks pembelajaran berbasis proyek yang terintegrasi STEM}

Fase atau Kegiatan Pembelajaran
Tahapan
Metode PjBL

Fase 1: Menunjukkan video/ ilustrasi kehidupan sesuai dengan topik

Menentukan pembelajaran (Science), Dimulai dengan sebuah investigasi pertanyaan mendalam, Topik sesuai dengan/ relevan dengan peserta didik, mendasar Mengumpulkan informasi, Peserta didik menetukan dan mengajukan pertanyaan

Fase 2: $\quad$ Perencanaan proyek dilakukan secara kolaboratif, berisi: Aturan Menyusun dalam perancangan proyek, Membaca literatur/referensi, perencanaan Pemilihan alat dan bahan pembuatan proyek (Engineering, proyek Technology), Prosedur kerja yang akan dilakukan, Mendesain awalan produk

Fase 3: $\quad$ Pengumpulan data ini dilakukan secara kolaboratif meliputi Menyusun jadwal kegiatan: Membuat timeline untuk menyelesaikan proyek (Engineering)

Fase 4:

Memonitor peserta didik dan kemajuan proyek
Monitoring dilakukan dengan memfasilitasi peserta didik pada setiap proses pembuatan produk (Technology, Engineering) 


\begin{tabular}{ll}
\hline $\begin{array}{l}\text { Fase 5: Menguji } \\
\text { hasil }\end{array}$ & Menguji proyek yang sudah jadi dan dengan melakukan variasi- \\
& variasi terhadap teknologi yang telah dibuat guna untuk \\
& membuktikan pertanyaan yang telah diajukan oleh peserta didik \\
& (Science, Technology, Engineering, Mathematics), Memberikan \\
& umpan balik tentang tingkat pemahaman yang sudah dicapai \\
& peserta didik \\
\hline Fase 6: & Mempresentasikan hasil proyek dan diskusi didepan kelas, \\
Mengevaluasi & Melakukan refleksi terhadap aktivitas pembuatan proyek dengan \\
pengalaman & mengungkapkan pengalaman serta kendala selama melakukan \\
& proyek (Science, Technology, Mathematics)
\end{tabular}

Komponen-komponen pendekatan STEM (Sains, Technology, Engineering, Meathematics) (Johnson, 2015) terintegrasi pada kegiatan pembelajaran proyek pembuatan teknologi sederhana menggunakan alat dan bahan yang sederhana, mudah untuk digunakan dan ditemukan ditunjukkan pada tabel 2.

Tabel 2. Komponen Integrasi STEM pada Pembelajaran Proyek

\begin{tabular}{|l|l|}
\hline Unsur & Penjelasan \\
\hline Science (Sains) & Hukum Newton \\
\hline Technology (Teknologi) & Teknologi sederhana \\
\hline Engineering (Teknik) & Desain/ rancangan dari teknologi sederhana \\
\hline Mathematics (Matematika) & Persamaan matematis Hukum I, II, III Newton \\
\hline
\end{tabular}

Kegiatan pembelajaran berbasis Proyek dengan pendekatan STEM dilakukan sebanyak 5 kali pertemuan ( 8 x 45 menit). Kemampuan peserta didik berfokus pada literasi teknologi dan sains peserta didik

Silabus dan RPP yang digunakan mengacu pada Permendikbud No. 22 Tahun 2016 dan berdasarkan kurikulum 2013 revisi dengan mengintegrasikan unsur STEM pada sintaks pembelajaran berbasis proyek. LKPD memuat permasalahan kehidupan sehari-hari. Tiga LKPD yang digunakan antara lain LKPD 1 bertujuan untuk mempelajari Hukum I dan II Newton, gaya normal, gaya berat dan gaya gesek, dengan menggunakan proyek mobil-mobilan. LKPD 2 bertujuan untuk mempelajari Hukum III Newton dengan menggunakan proyek kapal uap sederhana. LKPD 3 bertujuan untuk mempelajari Hukum I dan II Newton pada katrol sederhana. Kegiatan-kegiatan dalam LKPD menunjang kemampuan literasi teknologi dan sains peserta didik.

Data kemampuan literasi teknologi dan sains peserta didik diperoleh melalui hasil tes uraian. Sebelum dan sesudah peserta didik mengikuti pembelajaran. Analisis deskriptif peningkatan kemampuan literasi teknologi dan sains peserta didik menggunakan kategori ketercapaian yang ditentukan apabila terjadi peningkatan dari nilai pretes dan postes serta ketuntasan belajar siswa mencapai 75\% (KTSP MAN 1 Yogyakarata, 2020).

Angket respon peserta didik terhadap pembelajaran bertujuan untuk mengetahui respon peserta didik setelah mengikuti pembelajaran berbasis proyek dengan pendekatan STEM. Angket respon peserta didik diberikan diakhir pembelajaran berbasis proyek dengan pendekatan STEM ini. Kisi-kisi angket respon peserta didik terhadap pembelajaran proyek dengan pendekatan STEM terdistribusi dalam 20 pertanyaan terdiri dari tiga aspek, yaitu kepeminatan peserta didik dalam pembelajaran fisika, kebermanfaatan pembelajaran berbasis proyek STEM, dan kepemahaman peserta didik.

\section{HASIL DAN PEMBAHASAN}

Implementasi pembelajaran berbasis proyek dengan pendekatan STEM menggunakan perangkat pembelajaran silabus, RPP dan LKPD untuk mendukung proses pembelajaran. 
Sintaks-sintaks model pembelajaran berbasis proyek pada perangkat pembelajaran STEM, mengarahkan peserta didik untuk menemukan konsep fisika terkait Hukum Newton tentang gerak yang ada pada teknologi sederhana. Sintaks-sintaks pembelajaran mengarahkan peserta didik untuk paham akan teknologi, prinsip kerja dan penggunaan dari teknologi sederhana yang telah dibuat. Fase-fase pada model pembelajaran berbasis proyek berfungsi untuk memandu peserta didik dalam merancang teknologi sederhana dan untuk menemukan konsep fisika yang mendasari teknologi sederhana. LKPD pembelajaran berbasis proyek dengan pendekatan STEM memuat soal-soal yang terkait dengan literasi teknologi dan sains sehingga dapat memfasilitasi indikator-indikator literasi teknologi dan sains.

Untuk mencapai target kurikulum kompetensi dasar dijabarkan dalam indikatorindikator literasi teknologi dan sains untuk lima kali pertemuan. Pertemuan pertama dan kedua merupakan 6 langkah pembelajaran berbasis proyek yang terintegrasi STEM digunakan untuk membuat mobil-mobilan secara berkelompok ditunjukkan pada gambar 1.
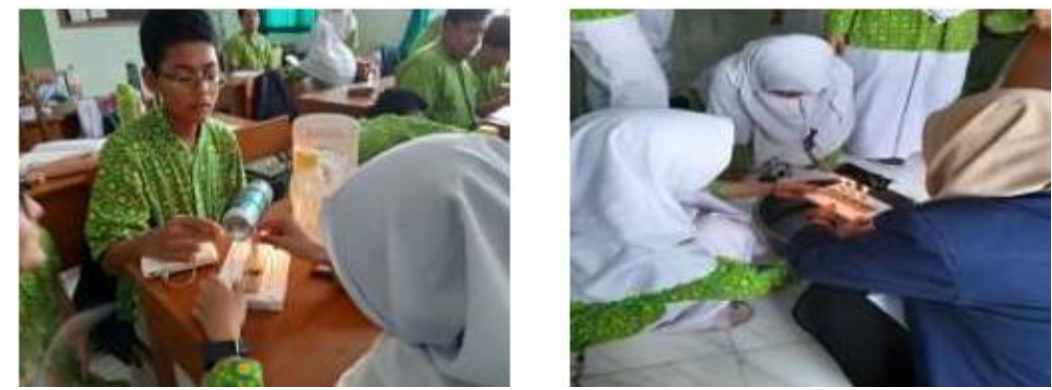

Gambar 1. Proyek Pembuatan Mobil-mobilan.

Langkah 1-4 pada model pembelajaran berbasis proyek dilakukan dengan persiapan dan pembuatan mobil-mobilan secara berkelompok. Langkah ke 5 pembelajaran berbasis proyek (menguj hasil), masing-masing kelompok menguji mobil-mobilan yang sudah jadi dan dengan melakukan variasi penambahan beban terhadap mobil-mobilan yang telah dibuat untuk membuktikan pertanyaan yang telah diajukan oleh peserta didik. Kegiatan menguji hasil terkait dengan percobaan mengenai gaya normal dan gaya berat, kelembaman benda (Hukum I Newton), pengaruh massa dan gaya suatu benda pada percepatan (Hukum II Newton). Kemudian langkah selanjutnya yaitu mengevaluasi pengalaman. Masing-masing kelompok mengkomunikasikan hasil diskusi, pengalaman serta kendala ketika membuat mobil-mobilan.

Pertemuan ketiga, ditunjukkan pada gambar 2, peserta didik membuat kapal uap sederhana. Langkah 1-4 dari sintaks pembelajaran berbasis proyek terintegrasi STEM digunakan untuk persiapan dan pembuatan kapal uap sederhana. Langkah ke 5 pembelajaran berbasis proyek (menguj hasil), masing-masing kelompok menguji kapal uap sederhana yang sudah jadi dengan meletakkan kapal uap sederhana diatas air yang telah disediakan. Kegiatan menguji hasil terkait dengan percobaan mengenai gaya aksi-reaksi yang berhubungan dengan Hukum III Newton serta penerapan Hukum III Newton dalam kehidupan sehari-hari.
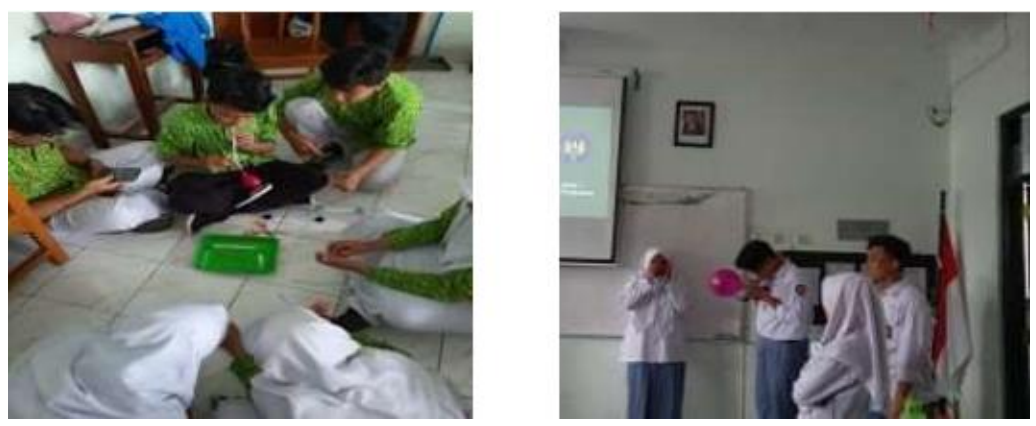

Gambar 2. Proyek Pembuatan Kapal Uap Sederhana 
Gambar 3 adalah proses pertemuan ke empat dan ke lima digunakan untuk membuat katrol sederhana secara berkelompok. Langkah 1-4 dari sintaks pembelajaran berbasis proyek terintegrasi STEM digunakan untuk persiapan dan pembuatan katrol sederhana. Langkah ke 5 pembelajaran berbasis proyek (menguj hasil), masingmasing kelompok menguji katrol sederhana sederhana dengan memberikan variasi massa pada katrol. Kegiatan menguji hasil terkait dengan percobaan terkait menganalisis Hukum I dan II Newton yang berlaku pada sistem katrol, serta menghitung percepatan yang bekerja pada sistem katrol sederhana.
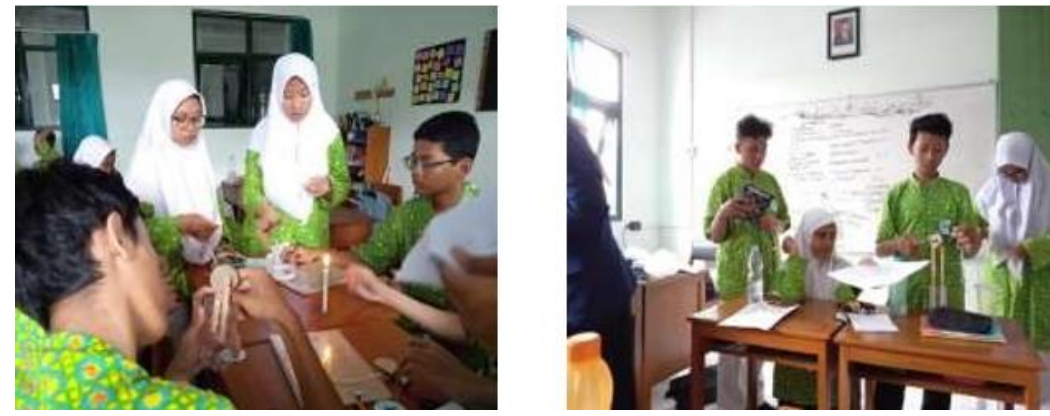

Gambar 3. Proyek Pembuatan Katrol Sederhana

Proses penilaian peserta didik sebelum dan setelah mengikuti pembelajaran berbasis proyek dengan pendekatan STEM, dapat dilihat pada gambar 4.
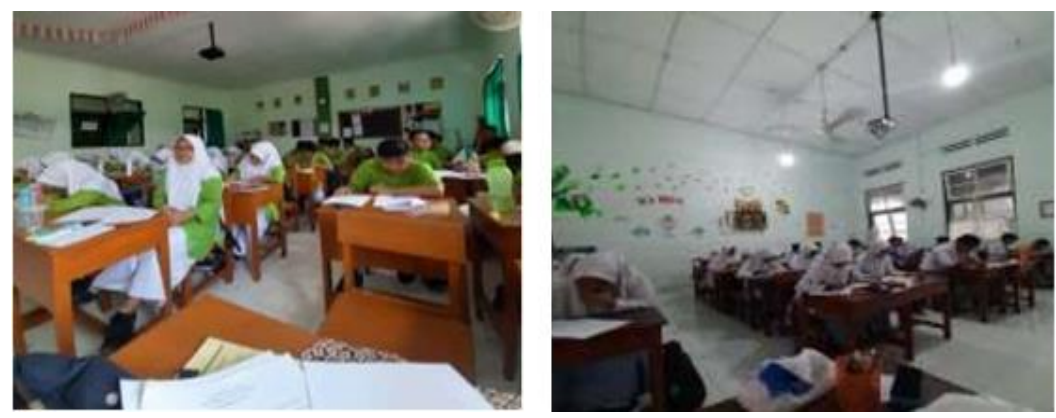

Gambar 4. Penilaian Pretes dan Postes

Data Respon peserta didik terhadap pembelajaran berbasis proyek dengan pendekatan STEM melalui angket terdapat tabel 3.

Tabel 3. Respon Siswa pada Pembelajaran Berbasis Proyek - STEM

\begin{tabular}{|c|c|c|c|c|c|c|c|c|c|c|c|c|c|c|c|c|c|c|c|c|}
\hline $\begin{array}{c}\text { No } \\
\text { Sis } \\
\text { wa }\end{array}$ & 1 & 2 & 3 & 4 & 5 & 6 & 7 & 8 & 9 & 1 & 1 & 1 & 1 & 1 & 1 & 1 & 1 & 1 & 1 & 2 \\
\hline Tot & 1 & 1 & 1 & 1 & 1 & 1 & 1 & 1 & 1 & 1 & 1 & 1 & 1 & 1 & 1 & 1 & 1 & 1 & 1 & 1 \\
al & 0 & 1 & 1 & 2 & 1 & 1 & 1 & 1 & 1 & 0 & 1 & 1 & 2 & 2 & 1 & 2 & 1 & 1 & 2 & 1 \\
& 7 & 6 & 4 & 1 & 1 & 6 & 0 & 2 & 5 & 9 & 8 & 5 & 3 & 2 & 6 & 3 & 9 & 3 & 1 & 5 \\
\hline$\%$ & 7 & 8 & 8 & 8 & 8 & 8 & 8 & 8 & 8 & 8 & 8 & 8 & 9 & 9 & 8 & 9 & 8 & 8 & 8 & 8 \\
& 9 & 5 & 4 & 9 & 2 & 5 & 1 & 2 & 5 & 0 & 7 & 5 & 0 & 0 & 5 & 0 & 8 & 3 & 9 & 5 \\
\hline Rer \\
ata
\end{tabular}

Hasil analisis menunjukkan bahwa respon peserta didik terhadap pembelajaran berbasis proyek-STEM sebesar $85 \%$ yang berada pada kategori sangat baik. Hal ini menunjukkan bahwa peserta didik merasa suasana belajar menyenangkan dan peserta didik menjadi aktif di kegiatan pembelajaran. 
Penilaian yang digunakan untuk mengukur kemampuan literasi teknologi dan sains peserta didik adalah melalui tes uraian. Data hasil penilaian pretes dan postes ditunjukkan pada tabel 4.

Tabel 4. Nilai Pretes dan Postes Pembelajaran Berbasis Proyek - STEM

\begin{tabular}{|l|c|c|c|c|}
\hline \multicolumn{4}{|c|}{ Nilai Literasi Sain } \\
\hline \multirow{2}{*}{$\begin{array}{c}\text { Keterang } \\
\text { an }\end{array}$} & \multicolumn{2}{|c|}{$\begin{array}{c}\text { Skor Rata- } \\
\text { rata }\end{array}$} & \multicolumn{2}{c|}{ Nilai rata-rata } \\
\cline { 2 - 5 } & $\begin{array}{c}\text { Prete } \\
\text { s }\end{array}$ & $\begin{array}{c}\text { Poste } \\
\text { s }\end{array}$ & $\begin{array}{c}\text { Prete } \\
\text { s }\end{array}$ & Postes \\
\hline Jumlah & 276 & 435 & 5 & $\begin{array}{c}1712, \\
5\end{array}$ \\
\hline Rata-rata & 8,63 & $\begin{array}{c}13,5 \\
9\end{array}$ & 53,52 & 84,96 \\
\hline
\end{tabular}

\begin{tabular}{|l|c|c|c|c|}
\hline \multicolumn{4}{|c|}{ Nilai Literasi Teknologi } \\
\hline \multirow{2}{*}{$\begin{array}{c}\text { Keterang } \\
\text { an }\end{array}$} & \multicolumn{2}{|c|}{$\begin{array}{c}\text { Skor Rata- } \\
\text { rata }\end{array}$} & \multicolumn{2}{c|}{ Nilai rata-rata } \\
\cline { 2 - 5 } & $\begin{array}{c}\text { Prete } \\
\text { s }\end{array}$ & $\begin{array}{c}\text { Poste } \\
\text { s }\end{array}$ & Pretes & Postes \\
\hline Jumlah & 161 & 311 & $\begin{array}{c}1341,6 \\
7\end{array}$ & $\begin{array}{c}2591,6 \\
7\end{array}$ \\
\hline Rata-rata & 5,03 & 9,72 & 41,93 & 80,99 \\
\hline
\end{tabular}

Hasil analisis nilai pretes dan postes literasi sain dan literasi teknologi pada tabel 4 menunjukkan bahwa terjadi peningkatan nilai dari pretes ke postes. Peningkatan nilai literasi teknologi dari 41,93 menjadi 80,99 dan literasi sain dari 53,52 menjadi 84,96. Hasil rerata nilai postes teknologi sebesar 80,99 dan nilai rerata postes literasi sain sebesar 84,96, menggambarkan bahwa pembelajaran berlangsung dengan baik, berjalan lancar dalam suasana dan kondisi pembelajaran yang menyenangkan, bermakna, kreatif, dinamis dan dialogis serta ketuntasannya melampaui nilai KKM sebesar 75. Dengan demikian, pembelajaran proyek berbasis masalah dengan pendekatan STEM dapat menunjukkan kepada peserta didik bagaimana konsep, prinsip, sains, teknologi, teknik, dan matematika digunakan secara terintegrasi untuk mengembangkan produk, proses, dan sistem yang bermanfaat bagi kehidupan manusia.

Hasil ini sejalan dengan yang dilakukan oleh Afriana (2016) menjelaskan bahwa pembelajaran berbasis proyek yang terintegrasi STEM dapat meningkatkan kemampuan literasi sains peserta didik. Yuliati (2018) menjelaskan bahwa pendekatan STEM mampu meningkatkan literasi sains peserta didik. Ngabekti (2019) menjelaskan bahwa pendekatan STEM telah berpengaruh pada kemampuan literasi teknologi dan sains peserta didik. Cydis (2015) dan Blanco et al (2017) menyebutkan bahwa pembelajaran proyek mampu meningkatkan literasi teknologi peserta didik. Peserta didik setelah berpartisipasi dalam pembelajaran berbasis proyek terintegrasi STEM, mereka merasa tertarik, senang dan termotivasi dalam belajar, hal ini sependapat dengan penelitian Samsudin (2020).

\section{KESIMPULAN}

Kesimpulan yang dapat diambil dari penulisan best practice tentang penerapan pembelajaran berbasis proyek dengan pendekatan STEM adalah : 1) Respon siswa terhadap pembelajaran berbasis masalah dengan pendekatan STEM sebesar 85\% dengan kategori sanga baik menunjukkan bahwa tiga aspek kepeminatan peserta didik dalam pembelajaran fisika, kebermanfaatan pembelajaran berbasis proyek dengan pendekatan STEM, dan kepemahaman peserta didik dapat dicapai dengan maksimal. 2) Terjadinya peningkatan nilai rerata literasi teknologi dari 41,93 menjadi 80,99 dan nilai rerata literasi sain dari 53,52 menjadi 84,96. Peningkatan pada pada literasi teknologi yaitu speserta didik dapat mengenal teknologi berdasarkan fungsinya, menggunakan pendekatan untuk memecahkan masalah yang bergantung pada aspek proses desain serta aspek memahami sistem yang bekerja pada teknologi. Peningkatan pada Literasi sains antara lain peserta didik dapat mengidentifikasi pertanyaan, memperoleh pengetahuan baru, menjelaskan fenomena sains, membuat kesimpulan dan memahami hubungan antara teknologi dan sains, serta memiliki sikap sain yang sangat baik pada proses pembelajaran. 3) Nilai rerata teknologi sebesar 80,99 dan nilai rerata postes literasi sain sebesar 84,96 menggambarkan bahwa ketuntasan hasil belajar dengan baik, berjalan lancar 
dalam suasana dan kondisi pembelajaran yang menyenangkan, bermakna, kreatif, dinamis dan dialogis melampaui nilai KKM sebesar 75. Dengan demikian, pembelajaran proyek berbasis masalah dengan pendekatan STEM dapat menunjukkan kepada peserta didik bagaimana konsep, prinsip, sains, teknologi, teknik, dan matematika digunakan secara terintegrasi untuk mengembangkan produk, proses, dan sistem yang bermanfaat bagi kehidupan manusia

\section{DAFTAR PUSTAKA}

Acedo, C., \& Hughes, C. (2014). Principles for learning and competences in the 21 st-century curriculum. Prospects, 44(4), 503-525.

http://dx.doi.org/10.1007/s11125-014-9330-1

Afriana, J., Permanasari, A., \& Fitriani, A. (2016). Penerapan project based learning terintegrasi STEM untuk meningkatkan literasi sains siswa ditinjau dari gender. Jurnal Inovasi Pendidikan IPA, 2(2), 202-212. http://dx.doi.org/10.21831/jipi.v2i2.8561

Ahmad, I. (2018). Proses pembelajaran digital dalam era revolusi industri 4.0. Direktur Jenderal Pembelajaran dan Kemahasiswaan. Kemenristek Dikti.

Akbar, A. (2017). Membudayakan Literasi dengan Program 6M di Sekolah Dasar. Jurnal Pendidikan Sekolah Dasar, 3(1), 42-52.

Akmam, A., Anshari, R., Amir, H., Jalinus, N., \& Amran, A. (2018). Influence of learning strategy of cognitive conflict on student misconception in computational physics course. In IOP Conf. Series: Materials Science and Engineering (Vol. 335, pp. 1-7). https://doi.org/10.1088/1757899X/335/1/012074

Alifa, D. M., Azzahroh, F., \& Pangestu, I. R. (2018). Penerapan Metode Stem (Science, Technology, Engineering, Mathematic) Berbasis Proyek Untuk Meningkatkan Kreativitas Siswa Sma Kelas Xi Pada Materi Gas Ideal. In Prosiding SNPS (Seminar Nasional Pendidikan Sains) (pp. 88-109).

Anjarsari, P., Prasetyo, Z. K., \& Susanti, K. (2020). Developing technology and engineering literacy for Junior High School students through STEM-based science learning. In Journal of Physics: Conference Series (Vol. 1440, No. 1, p. 012107). IOP Publishing. https://doi.org/10.1088/17426596/1440/1/012107

Archer-Bradshaw, R. E. (2017). Teaching for Scientific Literacy? An examination of instructional practices in Secondary Schools in Barbados. Research in Science Education, 47(1), 67-93.

Arief, M. K., \& Utari, S. (2015). Implementation Of Levels Of Inquiry On Science Learning To Improve Junior High School Student's Scientific Literacy Penerapan Levels Of Inquiry Pada Pembelajaran Ipa Untuk Meningkatkan Literasi Sains Peserta didik SMP. Jurnal Pendidikan Fisika. http://doi.org/10.15294/jpfi.v11i2.4233

Astuti, A. P., Mawarsari, V. D., Purnomo, H., \& Sediyono, E. (2020). The use of augmented reality-based learning media to develop the technology literacy of chemistry teachers in the 21st century. In AIP Conference Proceedings (Vol. 2215, No. 1, p. 020002). AIP Publishing LLC.

Avsec, S., \& Szewczyk-Zakrzewska, A. (2017). Predicting academic success and technological literacy in secondary education: a learning styles perspective. International

Journal of Technology and Design Education, 27(2), 233-250. https://doi.org/10.1007/s10798-015-9344-X

Bastion, S. (2014). The Development of a Valid and Reliable Measure of Technological Literacy for Adults (Doctoral dissertation, University of Kansas).

Blanco, T., Casas, R., Manchado-Pérez, E., Asensio, Á., \& López-Pérez, J. M. (2017). From the islands of knowledge to a shared understanding: interdisciplinarity and technology literacy for innovation in smart electronic product design. International Journal of Technology and Design Education, 27(2), 329-362. https://doi.org/10.1007/s10798015-9347-7 
Capraro, R. M., Capraro, M. M., \& Morgan, J. R. (Eds.). (2013). STEM projectbased learning: An integrated science, technology, engineering, and mathematics (STEM) approach. Springer Science \& Business Media.

Cydis, S. (2015). Authentic instruction and technology literacy. Journal of Learning Design, $8(1), 68-78$.

Dinçer, S. (2018). Are preservice teachers really literate enough to integrate technology in their classroom practice? Determining the technology literacy level of preservice teachers. Education and Information Technologies, 23(6), 2699-2718.

Hanif, S., Wijaya, A. F. C., \& Winarno, N. (2019). Enhancing Students' Creativity through STEM Project-Based Learning. Journal of Science Learning, 2 (2), 50-57.

Hugerat, M. (2016). How teaching science using project-based learning strategies affects the classroom learning environment. Learning Environments Research, 19(3), 383-395. http://doi.org/10.1007/s10984-016-9212-y

Irianto, P. O., \& Febrianti, L. Y. (2017, June). Pentingnya Penguasaan Literasi Bagi Generasi Muda Dalam Menghadapi Mea. In Proceedings Education and Language International Conference (Vol. 1, No. 1).

Jamali, S. M., Md Zain, A. N., Samsudin, M. A., \& Ale Ebrahim, N. (2017). Selfefficacy, scientific reasoning, and learning achievement in the STEM project-based learning literature. The Journal of Nusantara Studies (JONUS), 2, 29-43.

Kementrian Pendidikan dan Kebudayaan. 2013. Materi Pelatihan Guru: Implementasi Kurikulum 2013 SMA/MA, SMK/MAK Matematika. Jakarta: Kemdikbud.

Lestari, T. P., Sarwi, S., \& Sumarti, S. S. (2018). STEM-Based Project Based Learning Model to Increase Science Process and Creative Thinking Skills of 5th Grade. Journal of Primary Education, 7(1), 18-24.

Maharani, L., Rahayu, D. I., Amaliah, E., Rahayu, R., \& Saregar, A. (2019). Diagnostic Test with Four-Tier in Physics Learning: Case of Misconception in Newton's Law Material. In Journal of Physics: Conference Series (Vol. 1155, No. 1, p. 012022). IOP Publishing. http://doi.org/10.1088/1742-6596/1155/1/012022

Milaturrahmah, N., Mardiyana, M., \& Pramudya, I. (2017, September). Mathematics Learning Process with Science, Technology, Engineering, Mathematics (STEM) Approach in Indonesia. In Journal of Physics: Conference Series (Vol. 895, No. 1, p. 012030). IOP Publishing

Naraian, S., \& Surabian, M. (2014). New literacy studies: An alternative frame for preparing teachers to use assistive technology. Teacher Education and

Special Education, 37(4), $\quad$ http://doi.org/330-346. 10.1177/0888406414538843

Nopilda, L., \& Kristiawan, M. (2018). Gerakan Literasi Sekolah Berbasis

Pembelajaran Multiliterasi Sebuah Paradigma Pendidikan Abad Ke21. JMKSP (Jurnal Manajemen, Kepemimpinan, dan Supervisi

Pendidikan), 3(2), 216-231. http://dx.doi.org/10.31851/jmksp.v3i2.1862

Pearson, G. (2017). National academies piece on integrated STEM. The Journalof

Educational Research, 110(3), 224-226. http://dx.doi.org/10.1080/00220671.2017.1289781

Priatna, N., Martadipura, B. A. P., \& Lorenzia, S. (2019). Development of mathematic's teaching materials using project-based learning integrated STEM. In Journal of Physics: Conference Series (Vol. 1157, No. 4, p.

042006). IOP Publishing. https://doi.org/10.1088/17426596/1157/4/042006

Purwani, L. D., Sudargo, F., \& Surakusumah, W. (2018, May). Analysis of student's scientific literacy skills through socioscientific issue's test on biodiversity topics. In Journal of Physics: Conf. Series (Vol. 1013, p. 012019). https://doi.org/10.1088/17426596/1013/1/012019

Putri, S. D., \& Djamas, D. (2017). Pengembangan Perangkat Pembelajaran Fisika

Berbasis Keterampilan Berpikir Kritis dalam Problem-Based 
Learning. Jurnal Ilmiah Pendidikan Fisika Al-Biruni, $6(1), \quad 125$. https://doi.org/10.24042/jpifalbiruni.v6i1.648

Rahmayani, E., Irwandi, I., \& Rajibussalim, R. (2018, September). Developing worksheets through ISLE-based STEM approach and implementing them on senior high school students. In Journal of Physics: Conference Series (Vol. 1088, No. 1, p. 012091). IOP Publishing.

Ristekdikti. (2018). Pengembangan Iptek dan Pendidikan Tinggi di Era Revolusi Industri 4.0. Retrieved from https://www.ristekdikti.go.id/siaranpers/pengembanganiptekdanpendidikan-tinggi-di-era-revolusi-industri4-0/

Rusilowati, A., Kurniawati, L., Nugroho, S. E., \& Widiyatmoko, A. (2016). Developing an Instrument of Scientific Literacy Assessment on the Cycle Theme. International Journal of Environmental and Science Education, 11(12), 5718-5727.

Samsudin, M. A., Jamali, S. M., Md Zain, A. N., \& Ale Ebrahim, N. (2020). The Effect of STEM Project Based Learning on Self-Efficacy among High-School Physics Students. Journal of Turkish Science Education, 16(1), 94-108. https://doi.org/10.36681/tused.2020.15

Tim Pengembang Kurikulum. (2020). Kurikulum Tingkat Satuan Pendidikan MAN 1 Yogyakarta Tahun 2020.

Triyadi, S., Rozak, R. W. A., Tantowi, Y. A., Setiawan, H., \& Supriatna, E. (2019). Analisis Kemampuan Membaca Permulaan dan Pemanfaatannya dalam Merancang Pembelajaran Literasi Awal Berbasis Fabel. In Proceedings (Vol. 1, No. 2).

Utami, I. S., Septiyanto, R. F., Wibowo, F. C., \& Suryana, A. (2017). Pengembangan STEMA (Science, Technology, Engineering, Mathematic and Animation) Berbasis Kearifan Lokal dalam Pembelajaran Fisika. Jurnal Ilmiah Pendidikan Fisika Al-Biruni, 6(1), 6773. http://dx.doi.org/10.24042/jpifalbiruni.v6i1.1581

Yuliatin, D., Bachtiar, R. W., \& Prihandono, T. (2018). Pengaruh Sps Worksheet erhadap Kps Dasar Pada Materi Hukum Newton Di Sman 3 Jember. Fkip E-Proceeding, 3(1), 284291. 